\title{
ENTOMOFAGY - A VIABLE SOLUTION FOR SUPPORTING FOOD SECURITY
}

\author{
Violeta Elena Simion ${ }^{1 *}$, Rocsana Țoniș Bucea-Manea ${ }^{2}$, Amfim Adriana ${ }^{3}$, \\ Oliva Maria Dourado Martins ${ }^{4}$, Blagica Sekovska ${ }^{5}$ and Irina Dijmărescu ${ }^{6}$ \\ ${ }^{122) 3)}$ Spiru Haret University, Bucharest, România. \\ ${ }^{4)}$ UDCE of Instituto Politécnico de IPT, Tomar, Portugal. \\ ${ }^{5)}$ University St. Cyril and Methodius, Skopje, Republic of Macedonia. \\ ${ }^{6)}$ Clinical Emergency Hospital for Children Grigore Alexandrescu, Bucharest, \\ România.
}

Please cite this article as:

Simion, V.E., Țoniş Bucea-Manea, R., Amfim, A., Dourado Martins, O.M., Sekovska, B. and Dijmărescu, I., 2019. Entomofagy - A Viable Solution for Supporting Food Security. Amfiteatru Economic, 21(51), pp. 462-479.

DOI: $10.24818 / \mathrm{EA} / 2019 / 51 / 462$

\section{Article History}

Received: 29 December 2018

Revised: 7 February 2019

Accepted: 29 March 2019

\begin{abstract}
Entomophagy or the practice of eating insects has been known and practiced for millennia by people around the world, and being taken into account in countries where insect consumption is considered to be exotic behavior or the evolution of society begins to impose it.

Food security is a prerequisite for the welfare of the population and can be achieved by appropriately capitalizing on the natural resources available to Romania's agriculture. Its approach and development must be in two directions, strongly interrelated with each other, namely a quantitative one and a qualitative one. The quantitative aspect regards as a matter of priority the provision of the necessary amount of food to meet the physiological needs of a reference population, while the quality aspect focuses on the nutritional value of foods consumed by the population so that its health is not affected or compromised. Considering the two above-mentioned aspects, we consider that the practice of consuming edible insects presents several advantages, both quantitative and qualitative, which should not be neglected in ensuring food security. Innovation must be implemented throughout the agri-food chain, and entomophagy can be one of the viable solutions to support food security.

In order to emphasize the importance of entomophagy in ensuring food security, the paper brings to the fore a series os aspects regarding the review of the scientific literature in the field, the nutritional value of insects, the impact of insect food production on the environment, and consumer attitudes towards entomophagy. At the end of the paper, a small attempt is made to assess to what extent Romanian consumers are prepared to accept edible insects in their food.
\end{abstract}

Keywords: entomophagy, food security, edible insects, Romanian consumers.

JEL Classification: M3, I1, Q1, Q570

\footnotetext{
* Corresponding author, Violeta Elena Simion - simion.violeta.elena@gmail.com
} 


\section{Introduction}

The concept of food security, along with food and nutritional policy, a component of the food problem for all peoples, especially now in the era of combating food waste (Schmidhuber and Tubiello, 2007). If water has already been recognized as a global security issue, access to food is becoming a challenge not only for developing countries but it is now considered an economic priority of the entire world. Right to food is a fundamental right, but only a few countries have included it in their Constitution. In Romania, Chapter II Fundamental Rights and Freedoms, Art. 47 The Standard of living says "the state is obliged to take measures of economic development and social protection capable of providing citizens with a decent living standard'". This explanation assumes the right to reasonable living conditions (food, clothing, and housing) and their continuous improvement. The large discrepancies in the international agri-food system, climate change and the incoherence of sustainable economic policies are added, according to Organization of United Nation, World Bank and International Monetary Fund Statistics, in line with current trends, an estimate of population growth over the coming decades. At the same time, global resource consumption is steadily rising far beyond the regeneration capacity of the planet, as Earth Overshoot Day (EOD) marks each year, the date the Planet consumed more than it produced. For example, in 2018, this date was marked on August 1. Therefore, future generations will fight the scarcity of resources - water, energy, food. In the Report of the Romanian Academy on Romania's Food Safety and Security Strategy for the period 2015-2020-2030, attention is drawn to the fact that: "In recent years, the issue of food security of the population has returned to the present day due to global challenges, among which we mention the increase in food demand in the emerging countries of Asia and South America non-food uses given to agricultural production by the production of biofuels, but also because of the impact of climate change on agricultural production and food supply". In other words, human existence faces serious problems affecting food security.

At present, many causes contribute to an increase in food insecurity: increased demographic growth, global warming, the use of food resources as biofuels, natural disasters, and last but not least, in armed conflicts. José Graziano da Silva states in a Food and Agriculture Organization (FAO) report that "Today, 60 percent of people who are hungry are in countries affected by conflicts and 40 percent are in countries that have suffered from drought, one of the most devastating phenomena for production" (FAO, 2018). Under these conditions, edible insects are increasingly viewed as an alternative source of food. Their role is multiple and contradictory, from harm to human and animal health, the harmful effect in agriculture, to importance in ecology, plant reproduction, soil fertility, maintaining biological balance. Currently, the role of insects in food is becoming increasingly appreciated for the nutritional value they can provide as a source of food, especially for protein content (high biological value), fat (with an important content in essential fatty acids), mineral substances and vitamins.

Entomophagy or practice of insect eating, although known and practiced for millennia by peoples around the world, particularly in Asia, Africa, Central, and South America, is still taboo in many countries and/or is considered to be less accessible to the population. The most known insect Orders are: Coleoptera (cockroaches, beetles), Diptera (flies), Orthoptera (grasshoppers, locusts, crickets), Lepidoptera (caterpillars, moths), Isoptera (termites), Hymenoptera (bees, wasps, ants), Hemiptera (true bugs), and Odonata (dragonflies). Their utilization in food varies according to local preferences, socio-cultural context and region (Costa-Neto and Dunkel, 2016). Since 2010, FAO maintains a web portal 
(www.fao.org/forestry/edibleinsects) dedicated to edible insects, where relevant information on insect species used in food, its use and potential, and other relevant news are provided. According to this information, tropical countries are at the top of the list with about 250 species of insects consumed in Africa, 180 species in China and 160 species in South-East Asia, especially in the Mekong river. Of the total of insect eaters, in the proportion of $31 \%$ are consumed the species of roaches (Coleoptera Order). Under these circumstances, the practice of insect consumption can be viable ensuring food security.

\section{Review of scientific literature}

The global population will continue to grow, until around 9 billion people by roughly the middle of this century. A reduction in population growth phenomenon is increased wealth, and with higher purchasing power comes higher consumption and a greater demand for proteins, all of this increasing pressure on the food supply system. At the same time, the competition between producers for access to agricultural surfaces, water, and energy will be increasingly fierce, given that their impact on the environment will have to be constantly reduced (Godfray et al., 2010).

Edible insects are increasingly considered novel food and this concept seem to be emerging as a leading instrument for setting rules and standards for the use of insects in human foods. Regulations governing insects as food and feed sources are largely absent, which leads to the existence of at least two situations at international level, namely that, "for developed countries, the absence of clear legislation and norms guiding the use of insects as food and feed is among the major limiting factors hindering the industrial development of farming insects to supply the food and feed sectors. In developing countries, the use of insects for human or animal food is, in practice, more tolerated then regulated" (FAO, 2013). In areas where food security is fragile, edible insects must be promoted as food for nutritional, cultural and economic reasons. Although there are more and more scientific arguments that make edible insects a useful tool for limiting food waste, aspects of how they are accepted by consumers should not be neglected at all. A recent similar study has been done in Belgium, and consumers have indicated that the presence of insects should be clearly labeled on the packaging and that they wanted to be able to buy these products mainly from the supermarket (van Thielen et al., 2018). Western Europeans' aversion to including insects in their diet was a matter of prejudice or cultural conditioning "what we eat and what we do not eat is, after all, a matter of course and fashion (rather) than anything else" (van Huis, 2015). At the same time, edible insects are part of the traditional diet in over 113 countries from Asia, Africa, and South America. Tao and Li (2018) conclude, according to the FAO that the "world's population will be approaching 9 billion by 2050. As the number grows, natural resources such as land and water degrade fast. Edible insects, with their high feed conversion efficiency and fecundity, as well as their minimal growth space, are certainly an advantageous solution to current and future food security issues".

From a legislative perspective, the solution for edible insects to become an important resource for food security has a number of marketing limitations in the European Union (UE): there are no strict health regulations for setting up farms, there is a lack of orientation on mass growth insects and clarity of what insects to be authorized for a new food market, limited information on species consumed before May 15, 1997, which is needed to be classified as novel food, there is an EU restriction on feeding non-ruminant processed animal protein 
(PAP), including insect (in accordance with Regulation (EC) No 1069/2009, "insect flour is a PAP that must be processed in accordance with the rules of the regulation", insects and other invertebrates are classified as Category 3 and are not intended for the food chain (FAO, 2013).

Edible insects can contribute to food security and can be the solution to lack of nutrients, especially protein, given their high nutritional value, low greenhouse gas (GHG) emissions, reduced land requirements, and high conversion efficiency. Insect biomass production as raw material for animals and fish can be combined with biodegradation of manure, compost, and waste disinfection. Insects can partially replace the increasingly expensive ingredients in compound feed, livestock, and aquaculture. Cereals now used as animal feed, often accounting for half of the cost of meat production, could then be used for human consumption (van Huis, 2013). Also "considering the immense quantities of insect biomass needed to replace current protein-rich ingredients such as meal and oil from fish and soybeans, automated mass-rearing facilities that produce stable, reliable and safe products need to be developed. The challenge for this new industry will be to ensure the cost-effective, reliable production of insects biomass of high and consistent quality. Regulatory frameworks need to be developed. The close collaboration of government, industry, and academia will be essential for success" (FAO, 2014).

Religion has played an important role in peoples culture, which has in the past influenced the consumption of agri-food products. The literature of many religions (Christian, Jewish, Islamic) shows evidence of insect consumption. In Leviticus, the Third book of Moses, for example, locusts are presented as a source of food (FAO, 2013). Asian countries, South America and Africa where people live a predominantly rural life are much closer to having an agro-food system based on what nature can offer in rough form or after brief processing. Modern agriculture, extended to Western countries, is based on productivity, which greatly reduces the direct contact of man with nature. Mela (1999) affirms: "culture, under the influence of the environment, history, community structure, human efforts, mobility, and political and economic systems, defines the rules on what is edible and what is not". Native Americans, for example, were accustomed to eating grasshoppers, locusts, and crickets (Lockwood, 2004) while in South and South-East Asian countries, between 20-24 species of edible insects were identified in consumption, and in Africa, the number of them reaches up to 246 species (Ramos-Elorduy et al., 1997). Insect consumption for these peoples is vital to ensuring food security, being available, easily accessible and used for millennia, bringing a significant nutritional contribution to the daily ration.

Many countries are currently facing food insecurity and malnutrition. The World Food Program (WFP, 2015) estimates that around 805 million people worldwide do not have enough food that will affect their health and lifestyle. An FAO Report (2017) mentions that there are 821 million undernourished people, representing $10.9 \%$ of the global population. The highest rate of hunger is recorded in Asian developing countries (especially South Asia) and Africa (Sub-Saharan Africa), and 97\% of the undernourished population comes from these regions (Patel and Agnetta, 2016). The most important element of food security of the three - availability, access, and use or of the four including stability (Schmidhuber and Tubiello, 2007), it is certainly the availability of food. This element refers to the provision of food at the marked level and reflects very well the economic development of a country (Patel and Agnetta, 2016). 
Childhood malnutrition has the most serious consequences on the health of the population and has been reported to be the most important risk for causing pathological conditions and even death due to these (WFP, 2015). Among the major consequences of chronic undernutrition we list: premature death (about $35 \%$ of cases of infant mortality are reported with this cause); the use of more resources in health care for these diseases, to the detriment of other health services (increased costs for neonatal services needed for low birth weight babies, additional medical services needed for malnourished children and predisposing to many diseases); loss of productivity in adulthood (reduction of congenial skills, lower impact of education which leads to lower labor productivity); negative impact on the population of a country (malnutrition in the maternal age affects the health of future generations in the long term). Evidence continues to signal the alarming rise in the effects of malnutrition that currently affects one in nine people. The FAO Report from 2018 mention that "while some progress continues to be made in reducing child stunting, levels still remain unacceptably high. Nearly 151 million children under five - or over 22 percent - are affected by stunting in 2017”. José Graziano da Silva, FAO General Director, points out that failure to provide nutrients and equipotential in children and adults are currently two of the most serious food security and nutrition issues, both of which result in health damage of the population with consequences on labor productivity. It also mentions that many countries continue to fight the burden of malnutrition in all three forms: "malnutrition, micronutrient deficiencies and, at the same time, the rapid rise in obesity and overweight" (FAO, 2018). Adult obesity according to the FAO Report (2017) affected in the year 2016, 672 million people, representing $13.3 \%$ of the adult population. Under these conditions, entomophagy supports food security and can be a solution for all peoples, regardless of their degree of development.

\section{Nutritive value of edible insects}

The nutritional value of edible insects is given by their content in energy, protein, fats, carbohydrates, minerals, and vitamins and is comparable to the nutritional value of other sources of food of animal origin. The energy value of edible insects is given by their content in calorific nutrients and is influenced by a number of factors related to the species, the environment in which they live and the type of preparation. The FAO study (2013) mentions an ant species from Australia (Oecophylla spp.) as being the top of the energy value provided by insects, with $1272 \mathrm{kcal} / 100 \mathrm{~g}$. Increased energy also provides a termite species (Macrotermes subhyalinus) from Ivory Coast $(535 \mathrm{kcal} / 100 \mathrm{~g})$, a grasshoppers species (Chortoicetes terminifera) from Australia (499 kcal/100g) but also an ant species (Mymecocystus mellinger) from Mexic (404 kcal/100g). The Food Composition INFOOD and FAO Biodiversity Database, launched in 2010, collects data on the composition and consumption of food, including less-used food, to promote biodiversity. Version 1.0(PhyFoodComp.1.0 from 2018, contained in the Code group 08 the Code 01 subcategory Insects and grubs (ants, raw; insect larva; locust boiled; termite raw; termite roasted).

Certainly, the protein $(\mathrm{CP})$ is the most important nutrient in the insect composition. The evaluation of over 100 species of insects on protein content showed values ranging from 13 $14 \%$ to insects of the Hymenoptera, Lepidoptera and up to $60-70 \%$ for insects of the Coleoptera, Hemiptera, Odonata and Orthoptera Orders (Xiaoming et al., 2010). Insect larvae of the Ortoptera Order (Locusta migratoria, Acridium melanorhodon, Ruspolia differens) have a content of 14 to $18 \% \mathrm{CP}$ while in the adult stage the value may reach up to $28 \%$. A grasshopper's species (Sphenarium purpurascens) from Mexic, well-known in the 
gastronomy and culture of this people is distinguished by the highest protein values. They are collected only at certain times of the year (spring-summer), and in the adult stage they can have up to $35-48 \%$ CP. The larvae of insects from the Coleoptera Order (Rhynchophorus palmarum, R. phoenicis, Callipogon barbatus) can also reach content of $36 \%$ CP (FAO, 2013). By comparison, beef may have between 19 and 26\% CP, and chicken between 17 and $33 \%$ CP. Protein value of insects is also given by their content in essential amino acids, such as tryptophan, lysine, leucine, isoleucine. Thus, to an insect species (Tenebrio molitor) lysine content is $26,8 \mathrm{~g} / \mathrm{kg}$ dry matter (DM), in tryptophan $3,9 \mathrm{~g} / \mathrm{kg} \mathrm{DM}$, and in leucine $52,2 \mathrm{~g} / \mathrm{kg}$ $\mathrm{DM}$; by comparison, beef has insignificant content in tryptophan and only $42 \mathrm{~g} / \mathrm{kg} \mathrm{DM}$ in leucine (Finke, 2002)

The highest caloric value is given by fat, with 9.5 calories/gram. Fat content of insects is variable, influenced by insect species, but also by type of food consumed by them, ranging from 9\% EE/DM (ether extract/dry matter) at the variegated grasshopper (Zonocerus variegates) up to $67 \% \mathrm{EE} / \mathrm{DM}$ at the edible grasshopper (Ruspolia differens) (Womeni et al., 2009). Edible insects are an important source of fat rich in polyunsaturated fatty acids and

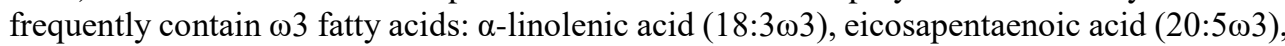
docosahexaenoic acid $(22: 6 \omega 3)$ and fatty acids from $\omega 6$ range of fatty acids: linoleic acid

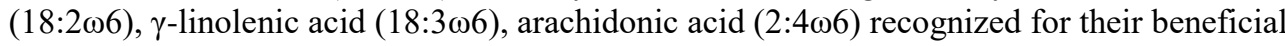
health effect in both adults and children as well as animals (Michaelsen et al., 2009; Yang et al., 2012).

Edible insects are also good sources of carbohydrates. Their carbohydrate content varies between $6.71 \%$ and $15.98 \%$ for some cockroaches species in the Hemiptera Order. Sun et al. (2007) also note the polysaccharide content of insects and their role in improving the immune system.

The content in micronutrients is also remarkable, especially by the amount of iron and zinc the insects contain. Compared to beef or chicken which iron content is 1.2 and $3 \mathrm{mg} \mathrm{Fe} / 100 \mathrm{~g}$ respectively (Sirimungkararat et al., 2010), the iron content of some insect species is much higher: $12 \mathrm{mg} \mathrm{Fe} / 100 \mathrm{~g}$ for the palm weevils (Rhynchophorus phoenicis), $20 \mathrm{mg} \mathrm{Fe} / 100 \mathrm{~g}$ for migratory locusts (Locusta migratoria) (Oonincx et al., 2010), and even $31 \mathrm{mg} \mathrm{Fe} / 100 \mathrm{~g}$ for the mopane caterpillars (Imbrasia belina) (Banjo, Lawal and Songonuga, 2006). Zinc content is also important, for example, for the weevil palm larvae the content can reach $26.5 \mathrm{mg}$ $\mathrm{Zn} / 100 \mathrm{~g}$ (Bukkems, 2005). Vitamins, both water-soluble and liposoluble, are found in significant quantities in edible insects. Thus, a termite species from Isoptera Order (Macrotermes nigeriensis) encountered in Africa and South-East Asia is remarked by 0.35 $\mathrm{mg} / 100 \mathrm{~g}$ retinol, $17.76 \mathrm{mg} / 100 \mathrm{~g}$ ascorbic acid, $1.56 \mathrm{mg} / 100 \mathrm{~g}$ riboflavin, $0,67 \mathrm{mg} / 100 \mathrm{~g}$ thiamine and $2.74 \mathrm{mg} / 100 \mathrm{~g}$ niacin (Igwe et al.., 2011). Bukkens (2005) has shown for a wide range of insects that thiamine has varied from $0,1-4 \mathrm{mg} / 100 \mathrm{~g}$ DM while riboflavin had a value between $0.11-8.9 \mathrm{mg} / 100 \mathrm{mg}$ to the analyzed species.

Despite this, it should be highlighted that the nutritional value of the nutrients in the composition is uncertain and variable depending on a number of factors: species, habitat, seasonality, feeding type, insect metamorphic stage, consumed parts, method of preparation etc. 


\section{The impact of edible insect food production on the environment}

At present, there is growing concern about the impact of modern lifestyle on the ecosystem from the point of view of climate change. The global warming phenomenon is a point of interest for a researcher in various fields to make intense efforts to find solutions to limit the negative effects of gase emissions as a result of anthropogenic activities that lead to climate change in many cases irreversible. Knowing that global food production represents about a quarter of all anthropogenic emissions of greenhouse gases, insect consumption is suggested as a more sustainable method (for example, low carbon dioxide emissions) and a healthier to consume animal protein (Miglieta et al., 2015).

More and more studies in the field support the fact that food production has a considerable negative impact on the environment such as deforestation, soil erosion, water pollution or gas emissions. In the absence of changes in food habits, global emissions of greenhouse gases (GHG) generated by food production are projected to increase by $80 \%$ in 2050 (Tilman and Clark, 2014). Many of these negative effects can be reduced by including edible insects in diet, they represent an alternative source of food, changing people's perception of entomophagy. At present, in increasingly active "environmental friendly" policies, it is advisable to curb aggressive environmental activities and use some friendly ones instead, such as using bicycles instead of cars. With regard to food behavior, the reduction in excessive meat consumption has systematically led to the attempt to find alternative sources of animal protein. In this respect, the production of edible insects is considered to be more sustainable than animal production for several reasons: reduced GHG emissions and ammonia (Oonincx et al., 2010), less required land area (Oonincx and de Boer, 2012), a more efficient conversion rate (van Huis, 2013). Among insect species "only cockroaches, termites, and scarab beetles produce $\mathrm{CH}_{4}$ from bacterial fermentation by Methanobacteriaceae" (Egert et al., 2013). These statements are also supported by Oonincx et al. (2010), which shows in a study that emissions to some species of insects (river larvae, crickets, and locusts) are less than 100 times that of pigs or cattle. Among the reasons that determine them used for human consumption is the fact that they have a high conversion rate of food. For example, crickets require a quantity of food six times smaller than cattle, four times smaller than sheep and twice lower that of pigs and broiler chickens to produce the same amount of protein. In many cases, insects can be grown on organic waste, allowing farmers to reduce the amount of grain used in animal feed, which requires a lot of energy and water resources. Meat production after processing is also much higher for insects (for example, $80 \%$ for cockroaches) than for beef $(55 \%)$, pig $(70 \%)$ or lamb (35\%) (FAO, 2018). By comparison, cricket production is 20 times more efficient as a source of protein than bovine meat production and generates 80 times less methane (Halloran et al., 2017). One of the scientific assumptions that support positive environmental effects, says that insect growth requires less food than beef production. For example, insects consume only 2 kilograms of feed to produce one pound of meat, while cattle require 8 kilograms of feed to generate 1 kilogram of beef (FAO, 2016).

Since 2008, several researchers have come together to review a wide range of published and unpublished research and information on insect growth and consumption. Only a multidisciplinary effort (technical experts specialized in forestry, animal husbandry, feed industry, legislation etc.) can establish food security policies "because of growing demand for meat and declining availability of agricultural land, there is an urgent need to find alternative protein sources. Edible insects can be produced with less environmental impact 
than livestock. Insect production may replace fishmeal used as a dietary supplement, especially in the rapidly growing aquaculture industry. Edible insects can alleviate waste disposal problems by growing them on organic by-products. About 2000 insect species are eaten worldwide, mostly in tropical countries" (van Huis, 2015).

Therefore, we can say that there are some points of view regarding the consumption of edible insects from the perspective of the environmental impact, which have scientific value and which we can find in the literature (high efficiency in feed conversion; reuse of organic waste; the emission of much lower amounts of contaminants for the environment; low water requirements, etc.) which could lead to increased consumer awareness of the need to replace meat consumption with insect consumption. However, studies on this subject are very few and insufficiently publicized so as to change the perception of the majority who feels more than the lack of desire to consume, even aversion. We consider the reasons to be multiple from lack of information, cultural or religious barriers to the lack of food legislation that allows insects to be marketed as food. To that end, we believe that multidisciplinary research on human perception should be stepped up and left to find the necessary and effective means to determine that edible insects can be an alternative to healthy and environmentally friendly food, for example, raw-vegan living has become a true lifestyle.

\section{Consumer attitude towards entomophagy}

Recognizing the strong global degradation of food security, a first step in tackling it is changing consumer behavior to create sustainable and environmentally friendly production. One solution may be to reduce meat consumption or to create alternative sources of protein. Edible insects could be considered substitutes for meat and protein-rich foods (Hartmann and Siegrist, 2017). However, the process of change in Western societies could be a long one. For new consumers, the initial motivation to consume insects as food is the feeling that they are ecological, sustainable, beneficial to health, the desire to taste, or the variety of diets (House, 2016). The negative attitudes of consumers to try this type of food have been backed by neophobia, while the positive attitudes of consumers to try have been backed by previous insect consumption. According to Wilkinson et al. (2018), only $21 \%$ of participants experienced this type of food. A view expressed by Menzoli et al. (2017), to overcome attitudinal barriers, is the intention to eat edible insects. The authors identified three main barriers: i) the feeling of disgust at the sight of the insects; ii) local culinary differences; iii) lack of products on the market. Recently, insects have gained interest in Western countries as an alternative to meat (Megido et al., 2016). However, thinking about changing consumer behavior, researches should distinguish between the curiosity of trying insect-based food and their adoption as food (Tan, Berg and Stieger, 2016). According to Oyserman (2017) culture influences in three ways human behavior: (1) culture as practices and social norms that determine the choice of a type of food; (2) culture as an ensemble of cultural mentalities (individualism/independence, collectivism/interdependence that have been acquired and have the role of guiding the perception of man; (3) culture as a set of specific practices in a particular society, time and place that influence consumer perception. The same view is supported by Lee and Lopetcharat (2017) which shows that consumer perception and behavior is influenced by culture. Also, nutritional value, texture, microstructure, and digestibility are factors that influence the choice of insects as food (Azzollini et al., 2018). According to Laureati et al. (2016), Italian consumers were not willing to eat insects but agreed to use them in animal feed. Age, gender, culture, and food neophobia were influential 
factors for adopting insects as food for humans and animals. An important role can be played by marketing policies that target consumer behavioral control by developing products with some similarity to Western culture as well as through strategies for communicating beneficial effects on human health as well favorable environmental impact (Menozzi et al., 2017). As a strengthening of the influence of the culinary aspect (what is seen in food), previous studies suggest that use in the processed form, so that insects are not visible, is beneficial (Megido et al., 2016; Wilkinson et al., 2018).

Insect preparation in food products, familiarity, and individual features are favorable for consumer acceptance. However, acceptability depends on the combination of products, while the familiarity and individual features of the food product play a minor role (Tan et al., 2016). According to Wilkinson et al. (2018), the transition phase for integrating insects into Western food culture will involve chopping, milling or incorporating insects into baked preparation (Wilkinson et al., 2018). Insect masking in flour for biscuits can be a solution. To motivate organic meats, for example, Hartmann and Siegrist (2017) suggested developing research in order to change behavior. In Western countries, adequate product design is important, but it is not accompanied by consumer acceptance of insects as food. To encourage this, insects as food need additional supplements to integrate them into food (Tan et al., 2016). Because of people's reluctance to eat new food, called food neophobia, the consumption of insects is very low (Megido et al., 2016). Their benefits, if highlighted, may be motivated to overcome food neophobia.

Some international agencies (eg. United Nations Organization for Agriculture) already recognize the nutritional benefits of entomophagy as well as environmentally friendly aspects, without mentioning their lower cost compared to meat, which will be reflected in the quality of food for people with purchasing power (Wilkinson et al., 2018). The nutritional and environmental benefits of edible insects promote an interest in optimizing insect production to develop the value chain (Alemu et al., 2017). For Italian consumers, environmental and nutritional benefits were considered positive, but not relevant. Sustainability has not played an important role in adopting insects as food (Laureati et al., 2016). The milled flour worm has improved the nutritional value of an extruded product. Microparticles with adapted digestive traits could be an innovative way and the protein concentration of snacks with $10 \%$ flour worms is in line with European food legislation (Azzollini et al., 2018). The pursuit of benefits seems to be insufficient in the face of attitudinal barriers that persist. In order for a consumer to try to consume insects, it is necessary to fulfill the main factors of influence such as the taste, appearance, quality, and safety of the food.

Socio-economic benefits of using insects for food and feed are various: poverty reduction, decreasing environmental pressure, decreasing of economic and nutritional incentives. Management measures need to balance ecological as well as social, cultural and economic objectives if they are to have any chance at success. Although insect gathering and rearing for food and feed in developing countries are carried out informally, selling the insects and/or their products at markets occurs in a more formal way. Insect markets and trade are relatively well structured within their own local contexts and form a network including producers/collectors, middlemen and sellers, and processors. Nonetheless, when insects are not seen as an important, or even real, human food source, it can be difficult for actors to enter or create new markets in countries where entomophagy is not popular. 


\section{Opinions of Romanian consumers regarding the consumption of edible insects}

In Romania, the use of insects is still a hard idea to accept, especially in terms of their inclusion in people's diet. Most Romanians believe that only certain animals may consume insects (those that are already used to this practice, for example, birds). Although it is an early stage with regard to this type of insect-based diet (Simion, Amfim and Belous, 2018), this idea attracts more and more followers, as it is an easily accessible source and is a nourishing and healthy feed for animals. In the conditions of the crisis of food resources, feeding of animals with fodder and healthy feed will also positively affect the human nutrition, by increasing the quantity and quality of meat production. However, it is worth considering that the opening of borders and travel to Asian countries, as well as media coverage of the Asian population culture and eating habits, have had a positive influence on the abuse of certain people, especially young people, with regard to insect consumption. Thus, the first research in this field was carried out in October 2018, on a sample of 73 respondents who study at Spiru Haret University in Bucharest. Approximately $10 \%$ of respondents said they consumed insect or insect products. Also, although they have accepted this source of feed for their own consumption, the views were contradictory: over $60 \%$ said they would not consume insects or insects products while over $58 \%$ said that if they are not visible in food, they could consume (Simion, Amfim and Belous, 2018).

From a methodological point of view, we can specify some of the essential aspects of the pioneering investigation of this article, described below and related to major questions, their transformation into research assumptions, sampling and sample structure, and the typology of questions applied to the questionnaire. The investigation exposed synthetic identified and analyzed the opinions of a slightly expanded group of Romanian students, more precisely a final sample of 122 respondents (56\% male and 44\% female, young dominant, over 20 years of age), self-extracting through the technique of volunteering, with the help of a questionnaire focused on a strict theme related to edible insects' consumption. The three major questions of the investigation were: i) What can be the alternative method of feeding the population?; ii) How willing are the respondents to try?; iii) What kind of insects and how should they be prepared to influence the target group's decision to consume them? the specific approach of obtaining the opinions and the processing of the resulting data brought together the hypothesis based on the questions from the research questionnaire in order to test and validate their possible correlations, determining the intensity of some associations between the resulting variables, as well as studying different orientations and trends focused on new consumer solutions in the context of an expected food crisis. The transformation of questions into hypotheses required the study by correlation matrices and tests of anticipated links through the elaboration of the question between the classic food crisis and the alternatives to this crisis (new sources of animal protein). Method of sampling, in such a pioneering investigation in Romania, was focused on a selection conducted through the technique of volunteering, starting from thematic novelty and conservatism and traditions specific to food consumption, without the possibility of determining the representativity error, and after the elaboration of the questionnaire its processing was done by CAWI technique (Computer Assisted Web Interview). The hierarchy and processing of opinions and implicitly the results have capitalized on a five-step classical Likert scale based on the allegations in the questionnaire. The results of this innovative research cannot be generalized at the level of Romania's population, but it is an absolutely necessary step for our further research, and even if they do not present statistical truths with sample errors, manage to capture opinions and expose associated perceptions among a predominantly young. Thus, the students as dominant

Vol. 21・ No. 51・ May 2019 
subjects investigated specified the level of agreement and disagreement with the statements in the questionnaire, contributing finally to the identification and parameterization of an incipient econometric model between variables resulting from the research of the young generation, even if it is not possible to specify their degree of statistical representativeness. Their associated responses identify a potential link between the type of insects, the form of their preparation and the decision to eat edible insects.

Opinions on the use of insects in animal feed

Following the application of the research tool, it was observed that most of the people questioned (62\%) believes that insects can be a good source of protein for animal feed while $21 \%$ disagree. Many of them think it should be normal or natural for animals. At the same time, the high protein content of the insects has been appreciated, being a very source of nitrogen, potassium and magnesium, a variable source of sodium and iron and rarely the adequate source of calcium. These observations can be considered important because insects are a sustainable source of food. Insects and parts of insects can be a safe alternative to traditional raw materials. These are important nutritional sources because of their protein content and good energy value (figure no. 1). A percentage of $17 \%$ of the respondents did not have a clear opinion in this regard. They believe protein insects can be replaced with other protein sources.

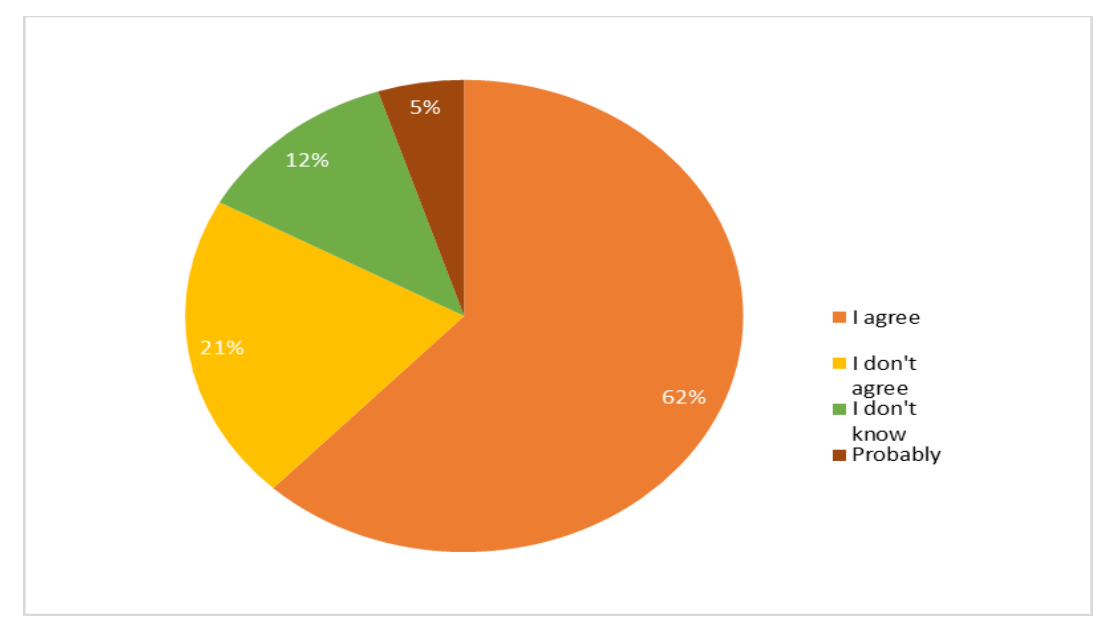

Figure no. 1: Panel opinion on the use of insects in animal feed

\section{Opinions regarding the consumption of insects/products based on edible insects}

When asked whether they consumed insects or foodstuff with insect composition, most respondents $(90 \%)$ said they had not used any insect-based preparation so far. Some of them accepted the idea of consuming vitamins extracted from insects, and some of the respondents would agree that they could be used as part of a balanced diet. The remaining $10 \%$ of respondents were distributed among people who already consumed as an insect protein source $(7 \%)$ and people who did not have a clear opinion. Some people consume ketchup having an insect pigment as a source of color, insects that they never consume as such. At the same time, he thinks everything is fine as long as all the hygiene rules and the legislation in force (figure no. 2). 


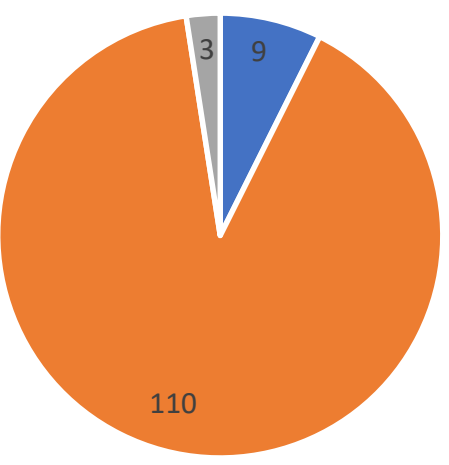

- Yes $\quad$ No $=$ I don't know

Figure no. 2: Panel opinion on the previous consumption of insects/ products based on edible insects

Opinions on the opportunity to consume insects/products based on edible insects

If the possibility of eating insects would arise, $61 \%$ of respondents would not eat these foods. A percentage of $39 \%$ of respondents who would agree to eat insects expressed their preference for locusts and ants. They would also consume arachnids, beetles, worms, bees, crickets, larvae and butterflies (figure no. 3). Some respondents would eat insects, but only those that are traditionally consumed in Asia and are more popular among consumers.

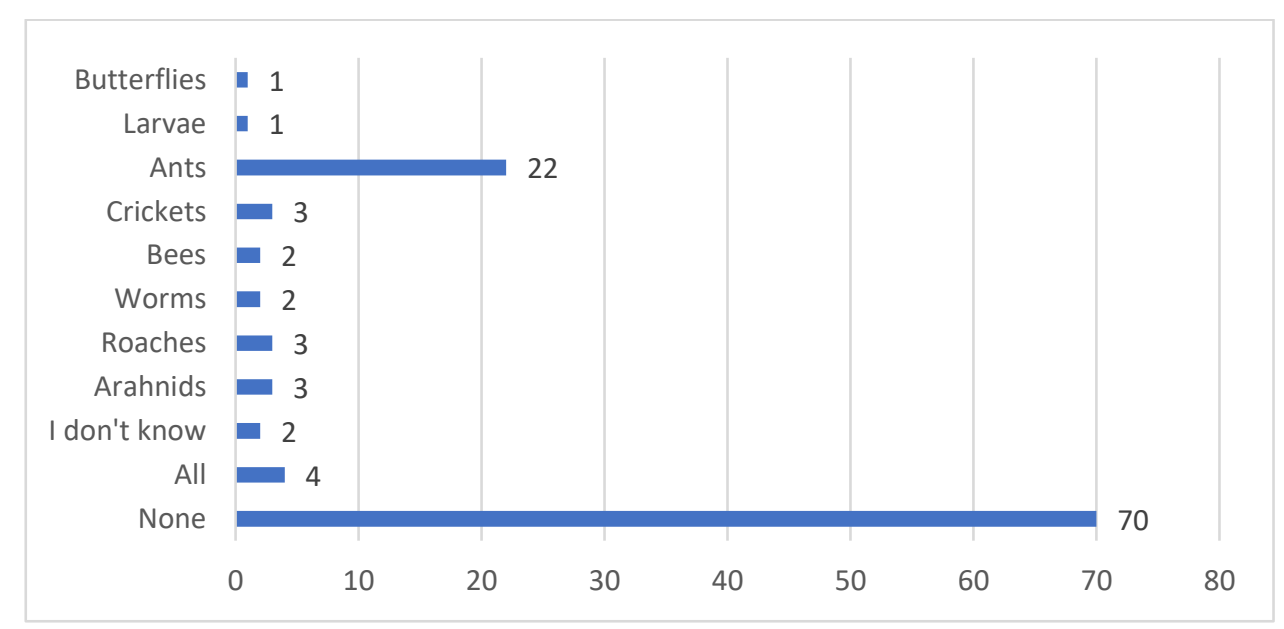

Figure no. 3: Panel opinion on insects' species which they would like to eat 


\section{Opinions on how to spot insects/products based on edible insects}

Many people would not want to see insects in the dish. For $55 \%$ of respondents it would be easier to consume insects if they are not visible (are prepared in the form of flour, for example). They must be cooked so as not to be refused from the beginning and to be under sanitary veterinary control.

From the analysis of opinions, if respondents had the opportunity to eat insects, they would like to choose what insect they will consume. Also the subjects of the sample claim that insects should be very well prepared or presented as flour to increase the likelihood of being consumed. It is noticed that the older respondents'age, the probability of eating insects is lower due to the conservatism and the traditionalism associated with maturity, as a result of the persistence of habits, the possible influences of a food behavior with which they are already accustomed. The gender of the respondents has no influence, according to the applied statistical tests, the difference between the results structured according to this variable is almost null, which means that women and men have similar opinions on the consumption of insect's food. Subjects believe that the type of insects and the mode of preparation are associated and influence the decision to eat insects if such a need or opportunity arises.

In the realization of the classical econometric regression model and its specification and parameterization, it started from the validation of the alternative hypothesis, with the hope that a significant difference will be identified between the opinions of the subpopulations delimited by two variables, namely the type of insects to be consumed and the method of preparation. It was found that the opinions of the respondents were significantly different on average, and the logarithmic regression model was the only apt after processing the data with the Eviews software package, to capture the association of opinion describing the use of insects as a source of protein in animal feed and the typological variable of these insects. The major intention of the investigation and final modeling was to highlight the emergence or presence of tendencies to change the young population's views on traditional food consumption. Even if the model holds a relatively value of $\mathrm{R}^{2}$ or R-squared of only 0.100077 , which would translate a limited determination to only $10 \%$ of the overall variation of the opinion on food consumption, starting from the variation of the insect type included (and even the method of preparing them), the value of the correlation ratio thus obtained becomes $\mathrm{R}=0.3163$ and the statistical link described is tested. Through the classical econometric modeling described in table 1 , the correlation that unifies the unifactorial model is specified and parameterized by a specific mathematical relationship:

$\log ($ opinion $)=0.508+0.245 \log ($ type $)$

where:

Opinion - the explicated or the resulting variable defined by the answer to the question "How do you appreciate the use of insects as a source of protein in animal feed?"

Type - the explanatory or factorial variable defined by the answer to the question "What are the insect species that you would agree to have on the plate?"

and subjected to testing, being virtually validating the non-linear statistical link between variables (according to a F-statistic $=13.34$ even at a significance threshold $\alpha=0,01$ (Table $\mathrm{F}=6,85$ ). 
Table no. 1: Logarithmic regression model achieved with the Eview software package

\begin{tabular}{|l|r|r|r|r|}
\hline \multicolumn{2}{|l|}{ Dependent Variable: LOG(OPINION) Method: Least Squares } & \\
\hline \multicolumn{2}{|c|}{ Sample: 1 122 Included observations: 122} & Std. Error & t-Statistic & Prob. \\
\hline Variable & Coefficient & 0.028900 & 17.58853 & 0.0000 \\
\hline COG(TYPE) & 0.245390 & 0.067174 & 3.653037 & 0.0004 \\
\hline R-squared & $\mathbf{0 . 1 0 0 0 7 7}$ & Mean dependent var & 0.573835 \\
Adjusted R-squared & 0.092577 & S.D. dependent var & 0.262738 \\
S.E. of regression & 0.250281 & Akaike info criterion & 0.083793 \\
Sum squared resid & 7.516875 & Schwarz criterion & 0.129761 \\
Log-likelihood & -3.111396 & Hannan-Quinn criter. & 0.102464 \\
F-statistic & $\mathbf{1 3 . 3 4 4 6 8}$ & Durbin-Watson stat & 2.272964 \\
Prob(F-statistic) & 0.000385 & & \\
\hline
\end{tabular}

The model described and validated by testing both the intensity of the correlation that synthesizes it according to the Fisher test and the inexistence of residual self-correlations with respect to the value of the Durbin-Watson test constitutes a pioneering, incipient and obvious boundary investigation but opens opportunities for broad scientific research in the context of an expected food crisis.

\section{Conclusions}

There is an enormous contradiction in the questionnaire answers because the vast majority, $55 \%$ of respondents, said that insects can be a food source if they are not visible in food, but at the same time $61 \%$ said they would not want to consume them. Moreover, $90 \%$ of respondents have not consumed insects so far. In contrast, $62 \%$ accept their inclusion in animal feed. Evidence leads to the interpretation that insects are not yet considered a source of food, even though they are cheaper and richer in nutrients. Unlike insect-based food, there are countless other foods that most people probably do not know how they are processed or do not think about their production. Meat, sausages, ham, hamburger etc involves the presence of blood and fat, in addition to the process (often cruel) that involve taking the animal's life. There are also dishes that use the intestine, stomach, and organs of animals. Considering that people can eat animals, blood, fats etc, the following question is asked: Why do they say they will not eat insects? Are cultural reasons important considering the fact that there are peoples? Should we consider biological or psychological aspects? On the other hand, people avoid thinking about how the animal was treated or what part of it is consumed. To solve this problem, two hypotheses can be considered: i) people do not know the process and composition of the foods they consume or ii) people do not think about what they eat.

It was considered unacceptable to introduce insects into food for the population without prior notice. For this reason, research considers valid the hypothesis of selective attention of the human being, in which people turn their attention to what is of interest to them. In an analogy with consumer behavior to introduce insect protein, we can think of at least two ways to use it simultaneously: i) dissociating food from reality by turning it into flour, pastry or putting it into cooked food or ii) ensure the experimentation of these types of food in consumption. Most of the social models agree with the premise that the intention precedes the behavior. The attitude and perception have an influence on the intention. So, the model to change the individual behavior would evaluate these variables. Furthermore, the innovation curve argues 
that it is necessary to exceed $16 \%$ of consumers in order for a product to be successful in the market.

Entomophagy can be a viable solution to support food security, although at present a significant percentage of Romanian consumers if they could, would not consume this type of food. Edible insects can be a sustainable source of food. On the one hand, it is necessary to accept them in the consumption of the population, on the other hand, to identify the most suitable resources so that they can be considered a food that supports food security. The consumer needs to be informed precisely, correctly and completely about the food he consumes and the extension of the research will help by the results obtained in the preparation of Romanian consumers for the acceptance of edible insects in food.

\section{References}

Alemu, M.H., Olsen, S.B., Vedel, S.E., Pambo, O.K. and Owino, V.O., 2017. Combining product attributes with recommendation and shopping location attributes to assess consumer preferences for insect-based food products. Food Quality \& Preference, [ejournal] 55, pp.45-57. doi: 10.1016/j.foodqual.2016.08.009.

Azzollini, D., Derossi, A., Fogliano, V., Lakemond, C.M.M. and Severini, C., 2018. Effects of formulation and process conditions on microstructure, texture, and digestibility of extruded insect-riched snacks. Innovative Food Science \& Emerging Technologies, [e-journal] 45, pp.344-353. doi: 10.1016/j.ifset.2017.11.017.

Banjo, A.D., Lawal, O.A., and Songonuga, E.A., 2006. The nutritional value of fourteen species of insects in southwestern Nigeria. African Journal of Biotechnology, 5, pp.281-301.

Bukkens, S.G.F., 2005. Insects in the human diet: nutritional aspects. In: Paoletti M. G. (ed.) Ecological Implications of Minilivestock; Role of Rodents, Frogs, Snails, and Insects for Sustainable Development. Science Publishers, New Hampshire. pp.545-577.

Costa-Neto, E.M. and Dunkel, F.V., 2016. Chapter 2 - Insects as Food: History, Culture, and Modern Use around the World. In: Aaron T. Dossey, Juan A. Morales-Ramos, M. Guadalupe Rojas. Insects as Sustainable Food Ingredients. Academic Press. pp. 29-60, [online] Available at: <http://www.sciencedirect.com/science/article/pii/ B9780128028568000028> [Accessed 22 November 2018].

Egert, M., Wagner B., Lemke T., Brune A. and Friedrich, M.V., 2003. Microbial Community Structure in Midgut and Hindgut of the Humus-Feeding Larva of Pachnoda ephippiata (Coleoptera: Scarabaeidae). Applied \& Environmental Microbiology, 69(11), pp. 6659-6668.

FAO Forestry Paper, 2013. Edible insects: future prospects for food and feed security. [pdf] Available at: <http://www.fao.org/docrep/018/i3253e/i3253epdf> [Accessed 22 November 2018].

FAO, IFAD, UNICEF, WFP, WHO., 2018. The State of Food Security and Nutrition in the World 2018. Building climate resilience for food security and nutrition. Rome, FAO. License: CC BY-NC-SA 3.0 IGO. [pdf] Available at: <http://www.fao.org/ 3/I9553EN/ i9553en.pdf.> [Accessed 22 November 2018].

Finke, M.D., 2002. Complete nutrient composition of commercially raised invertebrates used as food for insectivores. Zoo Biol, 21, pp.269-285. 
Food and Agriculture Organization of the United Nations, 2014. Edible insects and the environment [online] Available at: <http://www.fao.org/edible-insects/84744/en/> [Accessed 18 December 2018].

Food and Agriculture Organization of the United Nations, 2018. Insects for food and feed. [online] Available at: <http://www.fao.org/edible-insects/en/> [Accessed 18 December 2018].

Godfray, H.C.J., Beddington, J.R., Crute, I.R., Haddad, L., Lawrence, D., Muir, J.F., Pretty, J., Robinson, S., Thomas, S.M. and Toulmin, C., 2010. Food Security: The Challenge of Feeding 9 Billion People. Science, 327(5967), pp.812-818.

Halloran, A., Hanboonsong, Y., Roos, N. and Bruun, S., 2017. Life cycle assessment of cricket farming in north-eastern Thailand. Journal Clean Prod, 156, pp.83-94.

Hartmann, C. and Siegrist, M., 2017. Consumer perception and behavior regarding sustainable protein consumption: A systematic review. Trends in Food Science \& Technology, 61, pp.11-25.

House, J., 2016. Consumer acceptance of insect-based foods in the Netherlands: Academic and commercial implications. Appetite, 107, pp. 47-58.

Igwe, C.U., Ujowundu, C.O., Nwaogu, L.A. and Okwu, G.N., 2011. Chemical Analysis of an Edible African Termite, Macrotermes nigeriensis; a Potential Antidote to Food Security Problem. Biochem \& Anal Biochem, 1, pp.105.

Laureati, M., Proserpio, C., Jucker, C. and Savoldelli, S., 2016. New Sustainable Protein Sources: Consumers. Willingness to Adopt Insects as Feed and Food. Italian Journal of Food Science, 28(4), pp. 652-668.

Lee, H. and Lopetcharat, K., 2017. Effect of culture on sensory and consumer research: Asian perspectives. Current Opinion in Food Science, 15, pp.22-29.

Lockwood, J.A. 2004. Locust: the devastating rise and disappearance of the insect that sha ped the American frontier. New York: Basic Books.

Megido, C.R., Gierts, C., Blecker, C., Brostaux, Y., Haubruge, E., Alabi, T., Francis, F., 2016. Consumer acceptance of insect-based alternative meat products in Western countries. Food Quality \& Preference, 52, pp. 237-243.

Mela, D.J.,1999. Food choice and intake: the human factor. Proceedings of the Nutrition So ciety, 58, pp.513-521.

Menozzi, D., Sogari, G., Veneziani, M., Simioni, E. and Mora, C., 2017. Eating novel foods: An application of the Theory of Planned Behaviour to predict the consumption of an insect-based product. Food Quality \& Preference, 59, pp.27-34.

Michaelsen, K.F., Hoppe, C., Roos, N., Kaestel, P., Stougaard, M., Lauritzen, L., Mølgaard, C., Girma, T. and Friis, H., 2009. Choice of foods and ingredients for moderately malnourished children 6 months to 5 years of age. Food and Nutrition Bulletin, 30(3), pp.S343-S404.

Miglietta, P., De Leo F., Ruberti, M. and Massari, S., 2015. Mealworms for food: a water footprint perspective. Water, 7, pp.6190-203.

Oonincx, D.G.A.B., van Itterbeeck J., Heetkamp, M.J.W., van den Brand, H., van Loon, J.J.A., van Huis, A., 2010. An Exploration on Greenhouse Gas and Ammonia Production by Insect Species Suitable for Animal or Human Consumption, PLoS ONE, 5(12), pp.1-7. 
Oonincx, D.G.A.B. and De Boer, I.J.M., 2012. Environmental Impact of the Production of Mealworms as a Protein Source for Humans - A Life Cycle Assessment, PLoS ONE, 7(12), pp. 1-5.

Oyserman, D., 2017. Culture three ways: culture and subcultures within countries. Annu. Rev. Psychol., 68, pp.435-463.

Patel, D.R. and Agnetta, A., 2016. Food insecurity and nutrition. Journal of Alternative Medicine Research, 8(1), pp.17-22. [online] Available at: <http://search.ebscohost. com/login.aspx ?direct $=$ true $\& d b=a 9 h \& A N=114302369 \&$ site=ehost-live $>$ [Accessed 19 January 2019].

Ramos Elorduy, J. 1997. The importance of edible insects in the nutrition and economy of $\mathrm{p}$ eople of the rural areas of Mexico. Ecology of Food and Nutrition, 36, pp.347-366.

Raport Academia Română, 2014. Strategia siguranţei şi securităţii alimentare, [pdf] Available at: <https://acad.ro/viataAcademica/doc2015/i0307-StrategiaAgroalimRoPIOtiman.pdf> [Accessed 19 January 2019].

Schmidhuber, J. and Tubiello, F.N., 2007. Global food security under climate change, Proceedings of the National Academy of Sciences of the United States of America, 104(50), pp. 19703-19708.

Simion, V.E., Amfim, A. and Belous, M., 2018. Entomophagia - are Romanian consumers prepared for novel food? In: Volum de rezumate Conferinţa Naţională de Bioetică, Ediţia $a$ XIII- $a$, Iaşi, 8-10 Noiembrie 2018, pp.152-154.

Sirimungkararat, S., Saksirirat, W., Nopparat, T. and Natongkham, A., 2010. Edible products from eri and mulberry silkworms in Thailand. In: Durst P. B., Johnson D. V., Leslie R. L., Shono K. (eds.) Forest Insects as Food: Humans Bite Back, Proceedings of a workshop on Asia-Pacific Resources and Their Potential for Development. FAO Regional Office for Asia and the Pacific, Bangkok. pp.189-200.

Sun, L., Feng, Y., He, Z., Ma, T. and Zhang, X., 2007. Studies on alkaline solution extraction of polysaccharide from silkworm pupa and its immunomodulating activities. Forest Res., 20, pp.782-786.

Tan, H.S.G., van den Berg, E. and Stieger, M., 2016. The influence of product preparation, familiarity and individual traits on the consumer acceptance of insects as food, Food Quality \& Preference, 52, pp. 222-231.

Tao, J. and Li, Y.O., 2018. Edible insects as a means to address global malnutrition and food insecurity issues. Food Quality and Safety, [e-journal] 2(1), pp. 18. https://doi.org/ 10.1093/fqsafe/fyy001.

Tilman, D. and Clark, M., 2014. Global diets link environmental sustainability and human health, Nature, 515(7528), pp.518-522.

van Thielen, L., Vermuyten, S., Storms, B., Rumpold, B. and Van Campenhout, L., 2018. Consumer acceptance of foods containing edible insects in Belgium two years after their introduction to the market. Journal of Insects as Food and Feed, [e-journal] 0(0), pp.1-10.

van Huis, A., 2013. Potential of insects as food and feed in assuring food security. Annual Review of Entomology, [e-journal] 58(1), pp.563-583.

van Huis, A., 2015. Edible insects contributing to food security? Agriculture and Food Security, [e-journal] 4(20), pp.578-586. 
Wilkinson, K., Muhlhausler, B., Motley, C., Crump, A., Bray, H. and Ankeny, R., 2018. Australian Consumers' Awareness and Acceptance of Insects as Food. Insects (20754450), 9(2), p. N.PAG. doi: 10.3390/insects9020044.

WFP, 2015. Hunger Statistics. [online] Available at: 〈https://www1.wfp.org/zero-hunger> [Accessed 19 January 2019].

Womeni, H.M., Linder, M., Tiencheu, B., Mbiapo, F.T., Villeneuve, P., Fanni, J. and Parmentier, M., 2009. Oils of insects and larvae consumed in Africa: potential sources of polyunsaturated fatty acids. [online] Available at: <https://www.ocljournal.org/articles/ocl/pdf/2009/04/ocl2009164p230.pdf.> [Accessed 19 January 2019].

Xiaoming, C., Ying, F., Hong, Z, Zhiyong, C., 2010. Review of the nutritive value of edible insects. In: Durst, D.V. Johnson, R.L. Leslie and K. Shono. Forest insects as food: humans bite back, proceedings of a workshop on Asia-Pacific resources and their potential for development. Bangkok, FAO Regional Office for Asia and the Pacific.

Yang, X., Zhang, Y., Lin, J., Pen, A., Ying, C., Cao, W. and Mao, L. 2012. A lower proportion of dietary saturated/monounsaturated/polyunsaturated fatty acids reduces the expression of adiponectin in rats a fed a high-fat diet. Nutrition Research, 32(4), pp.285-291. 